\title{
Common Policy but Different Outcomes: Structural Change in Family Farms of Central and East European Countries after Their Accession to the EU
}

\author{
Philip Kostov ${ }^{1}$ and Sophia Davidova ${ }^{2, *}$ \\ 1 School of Business, University of Central Lancashire, Preston PR1 2HE, UK; pkostov@uclan.ac.uk \\ 2 School of Economics, University of Kent, Canterbury CT2 7NZ, UK \\ * Correspondence: S.M.Davidova@kent.ac.uk; Tel.: +44-(0)-1227-824764
}

Citation: Kostov, P.; Davidova, S. Common Policy but Different Outcomes: Structural Change in Family Farms of Central and East European Countries after Their Accession to the EU. Agriculture 2021, 11, 1074. https://doi.org/10.3390/ agriculture11111074

Academic Editor: Ayal Kimhi

Received: 26 September 2021

Accepted: 27 October 2021

Published: 31 October 2021

Publisher's Note: MDPI stays neutral with regard to jurisdictional claims in published maps and institutional affiliations.

\section{Copyright: (c) 2021 by the authors.} Licensee MDPI, Basel, Switzerland. This article is an open access article distributed under the terms and conditions of the Creative Commons Attribution (CC BY) license (https:// creativecommons.org/licenses/by/ $4.0 /)$.

\begin{abstract}
This paper investigates structural change in family farming in ten EU New Member States from Central and Eastern Europe which can be treated as a borderline between transition and developed economies. The paper proposes that farms using at least one Annual Work Unit (AWU) family labour are classified as family since it is considered that engaging less than one full-time family member may not show commitment to the family operation. The Oaxaca-Blinder decomposition is employed to analyse the drivers of structural change at a farm level, i.e., the extent to which it is technology or endowment driven. To compare the developments in different countries, the changes are presented in relative terms in order to reveal the relative distance travelled by the structural change in individual New Member States alongside the relative importance of technology and endowments changes. The estimation of a translog production function by country is used to derive the corresponding decompositions. Empirical analysis is based on data from the EU Farm Accountancy Data Network (FADN) for two time points-2007, when the last of the ten CEECs joined the EU-Bulgaria and Romania, and 2015 to investigate structural change during the first decade of EU membership. The results show that the differences in the initial conditions and the adjustments to the CAP have brought about quite a diverse picture concerning the changes in output in the family and non-family farms in the NMS. The a priori expected dynamics of positive output growth in family farms and negative in the non-family has only materialised in Latvia, Romania and Slovakia. The decomposition of output changes suggests a positive effect of technical change in family farms only in the early years of EU accession. Concerning endowments, their effect on structural change is mostly positive with the only exception of Slovenia. This suggests that the family farming sector grows by accumulating productive resources. However, this growth has not always materialised in increase of family farms output.
\end{abstract}

Keywords: structural change; family farms; EU New Member States; technological change; endowment; Oaxaca-Blinder technique

\section{Introduction}

This paper investigates structural change in family farming in ten EU New Member States (NMS), which can be treated as a borderline between transition and developed economies, i.e., Bulgaria, Czechia, Estonia, Hungary, Latvia, Lithuania, Poland, Romania, Slovakia, and Slovenia. The objective is to examine to what extent structural change is technology or endowments driven.

Structural change can be defined as the process of "recombining and redeploying the resources used in agriculture" [1]. Changes in the mix of land, labour, and capital used in farm production, in parallel with the application of new technologies and equipment, usually lead to an increase of competitiveness and efficiency of the agricultural sector. From this point of view, structural change is a positive and politically desired development. 
At the farm level, structural change is most often linked to the capital and mechanisation of farm operations, increased use of purchased inputs, and greater farm specialisation.

Usually, one of the factors that affects structural change is public policy [2]. There is a natural experiment that, with their accession to the EU, all Central and East European countries (CEECs) moved to the EU Common Agricultural Policy (CAP). Although there are some modalities in the CAP implementation, the main CAP measures including market regulations and decoupled income support to farmers are common. The CAP support, particularly direct income payments, represents a secure stream of income and facilitate farmers' access to credit since borrowers can offer a greater repayment capacity and this helps farm investment. The response to policy support has been heterogeneous. Some farmers managed to take advantage of policy transfers, and their businesses experienced accelerated structural change, while others were lagging behind, experiencing a sluggish change or were unable to face the competitive pressure in the EU Single Market and exited the sector.

In view of the above, the paper focuses on a comparative picture of structural change in family farming in different EU NMS assuming almost common policy environment post-accession to the EU. However, it should be noted that the EU membership and the adoption of the CAP have had different consequences for structural change in different countries. The consequences were influenced by the pre-accession farm structures, land tenure system and the pre-accession support to agriculture, which in turn were influenced by past developments, i.e., the initial conditions before the start of the economic reforms in late 1980s and early 1990s, and the politically chosen path of these reforms.

We focus specifically on family farms since structural change is central for family farming as it is a factor that helps offset certain disadvantages of family farms in respect to economic efficiency, access to farming resources, such as land and capital, and access to markets, particularly in terms of bargaining power in the food chain. Since they co-exist with non-family types of organisation of agricultural production, family farms need to compete not only in terms of efficiency (scale, productivity) but also in terms of innovation and entrepreneurship, and, from this point of view, the uptake of new technologies and the weight of technology in structural change is a central issue [3].

Family farming covers a wide range of farm types and sizes, with both full- and part-time farmers, and farmers with and without other gainful activities. The objectives of some family farms are focused on commercial farm business operations, while others produce mainly to satisfy household food needs, the so-called semi-subsistence farms, and a third group includes "lifestyle" (often called "hobby") farms, belonging to families with substantial non-agricultural income.

Family farm and family farmer may be defined in several ways. Definitions can be based on share of family labour, on ownership and control (and, thus, succession between generations), on legal status (sole holders), or on who bears the business risk. The approach in this paper is based on labour input, i.e., those farms that use at least one Annual Work Unit (AWU) family labour are defined as family. It is considered that engaging less than one full-time family member may not show commitment to the family operation and, hence, such farms may either fall into the category of non-family businesses based mainly on hired labour, or may generate utility as hobby farms contributing very little to household incomes. Our proposed threshold is lower compared to the some used, i.e., of up to 2 AWUs [4]. It should be noted that this higher threshold implicitly focused on West European agriculture, while, in many CEECs, such a definition would exclude a large proportion of smaller family farms.

Empirical analysis is based on data from the EU Farm Accountancy Data Network (FADN). The basic FADN sampling unit is the commercial holding, i.e., "a farm which is large enough to provide a main activity for the farmer and a level of income sufficient to support his or her family" [5]. Data availability for each country is from the year of accession to the EU of the last two-Bulgaria and Romania, i.e., 2007, and annual comparable datasets for all countries were available to the authors for the period to 2015 including. 
In order to analyse the causes of structural change, i.e., the extent to which the structural change is technology or endowment driven (or driven by interaction of these two), the analysis employs Oaxaca-Blinder technique [6,7]. To compare developments in different countries, the changes are presented in relative terms in order to reveal the relative distance travelled by the structural change in individual countries alongside the relative importance of technology and endowment changes. The estimation of a translog production function by country for all family farms in the FADN database, as defined in the paper, is used to derive the corresponding decompositions.

\section{Background to Structural Change in CEECs}

In the last three decades, one of the main drivers of changes in the farm structures and output in NMSs from Central and Eastern Europe were the market reforms across all economic sectors taking place at the same time as major political reforms in the late 1980s and early 1990s. Important factors affecting structural change in agriculture were institutional reforms, which reinstated private property rights in land and privatised non-land farm assets.

A conceptual model to investigate structural change in the ten CEECs which joined the European Union (EU) in the 2000s indicates two areas which we assume to influence directly or indirectly the structural change in family farming: the past development, i.e., the initial conditions at the start of the market reforms in the late 1980s and early 1990s, and the measures and speed of national policy reforms [8]. Both affect the way individual countries have adjusted to the implementation of the EU CAP post-accession. The implementation of the CAP and the longer-term effects of the initial conditions, i.e., whether agriculture was mainly collectivised pre-reform, as in e.g., Bulgaria, Czechia, and Slovakia, or was organised in predominantly small private farms, e.g., in Poland and Slovenia, are factors that have influenced the speed and depth of structural change of family farms in individual CEECs.

In respect to the initial conditions, at the start of the reform process, the main debate focused on macroeconomic reforms. Experts argued that at the centre of this debate lied the fourfold problem of deciding the speed of implementation of institutional changes, the sequence of reforms in the various economic sectors, their relation to management measures and the depth of the reforms themselves [9]. Overwhelmingly, a sharp decline in output was observed in the first years of transition. Two theoretical explanations were put forward for the decline in output which are relevant to agriculture. Some models explained the sharp decline by sector-specific capital that could not be turned to alternative uses and the necessary time to build new capital [10]. Agriculture is one of the sectors with highly specific and largely immobile capital (e.g., agricultural land). The second theoretical explanation was based on the imperfections in the credit market. In agriculture, they hindered the access of state and collective farms, which at the beginning of transition were the main producers in most of the CEECs, to capital necessary to maintain the level of production and this brought about a sharp decline of output.

The general macroeconomic reforms have strongly affected agriculture [11]. Apart from this, several sectoral reform processes were central to the development of the farm economy, including agricultural price liberalisation and terms of trade development against agriculture, land reforms, farm restructuring, and liberalisation of labour market resulting in deep adjustments of farm labour. It should be noted that these reforms developed in parallel and have been interdependent. For example, land restitution brought about farm restructuring with a gradual decrease in the size of state and collective farms, and development of family farms, many of which were semi-subsistence.

The characteristics of national agricultural post-communist reforms which affected the size and proliferation of family farms, and their structural change analysed in this paper, are in Table 1. 
Table 1. Implications of post-communist land reforms for family farms in CEECs.

\begin{tabular}{|c|c|c|}
\hline Countries & Characteristics of Land Reform & Outcome for Farm Structures \\
\hline Bulgaria & $\begin{array}{l}\text { Restitution of land rights as they were } \\
\text { in 1946; privatisation of state land } \\
\text { through tenders }\end{array}$ & $\begin{array}{c}\text { Small family farms; co-ownership } \\
\text { between heirs; large corporate farms } \\
\text { through lease agreements with private } \\
\text { owners; overall result-a dual farm } \\
\text { structure }\end{array}$ \\
\hline Czechia & $\begin{array}{c}\text { Restitution of land rights to private } \\
\text { owners or their heirs as they were in } \\
1948\end{array}$ & $\begin{array}{l}\text { Due to fragmented ownership most } \\
\text { land was leased out by private owners } \\
\text { to large corporate farms, the latter } \\
\text { maintained as a predominant farm } \\
\text { structure }\end{array}$ \\
\hline Estonia & $\begin{array}{l}\text { Restitutions of land rights as they were } \\
\text { in the 1940s before WWII; privatisation } \\
\text { of state land through sales }\end{array}$ & $\begin{array}{l}\text { Small farms; more than half of utilised } \\
\text { agricultural area used through lease } \\
\text { agreements }\end{array}$ \\
\hline Hungary & $\begin{array}{l}\text { Compensation of former owners } \\
\text { instead of physical restitution; land } \\
\text { distributed to current users; state land } \\
\text { sold at auctions in rural areas }\end{array}$ & $\begin{array}{c}\text { Very mixed structure small subsistence } \\
\text { farms; medium-sized family farms; } \\
\text { large corporate farms based fully on } \\
\text { leased land }\end{array}$ \\
\hline Latvia & $\begin{array}{l}\text { Restitutions of land rights as they were } \\
\text { in the 1940s before WWII or } \\
\text { compensation initially capped at } 50 \text { ha } \\
\text { and later increased to } 100 \text { ha; } \\
\text { privatisation of state land initially to } \\
\text { household plots }\end{array}$ & $\begin{array}{l}\text { Small and medium-sized family farms; } \\
\text { proliferation of lease agreements }\end{array}$ \\
\hline Poland & $\begin{array}{l}\text { Did not proceed to restitution and left } \\
\text { the land to small peasants who } \\
\text { cultivated it pre-reform; privatisation of } \\
\text { state land with preference to } \\
\text { commercial family farms }\end{array}$ & $\begin{array}{l}\text { Farm structures vary depending on the } \\
\text { region-very small in south and east; } \\
\text { medium-sized commercial farms in } \\
\text { north and west }\end{array}$ \\
\hline Romania & $\begin{array}{l}\text { Liquidation of collective farms; } \\
\text { restitution initially capped at } 10 \\
\text { ha/family later increased to } 30 \text { ha }\end{array}$ & $\begin{array}{c}\text { A large number of small subsistence } \\
\text { family farms; low number of corporate } \\
\text { farms; some larger family farms and } \\
\text { larger farms managed by agricultural } \\
\text { associations }\end{array}$ \\
\hline Slovakia & $\begin{array}{l}\text { Similar to Czechia; new private } \\
\text { cooperatives continued the activity of } \\
\text { collective farms; agricultural policy did } \\
\text { not encourage the break-up of large } \\
\text { corporate farms }\end{array}$ & $\begin{array}{c}\text { Due to fragmented ownership structure } \\
\text { most land leased out by private owners } \\
\text { to large corporate farms; very small } \\
\text { family farms }\end{array}$ \\
\hline Slovenia & $\begin{array}{l}\text { Small existing owner-operated farms } \\
\text { maintained; restitution of state land to } \\
\text { previous owners }\end{array}$ & Many relatively small family farms \\
\hline
\end{tabular}

Over time, the importance of the pre-reform initial conditions has decreased [11], although they continued to influence to some degree the situation in agriculture just before and during the first years of accession to the EU.

Before the EU accession, the commentators were unanimous that there was a substantial gap between the CEECs and the established EU-15 Member States since the former were less developed and more agricultural. This was true at the time, but, in the first years post-accession, CEECs experienced quick agricultural adjustments (Table 2). 
Table 2. Changes in labour directly employed on the farm, number of sole holder farms, and standard output.

\begin{tabular}{cccccccccc}
\hline Country & $\begin{array}{c}\text { Labour } \\
\text { (AWU) }\end{array}$ & $\begin{array}{c}\mathbf{2 0 0 7 / 2 0 0 5} \\
\text { SO } \\
\text { (Euro) }\end{array}$ & $\begin{array}{c}\text { No of } \\
\text { Farms }\end{array}$ & $\begin{array}{c}\text { Labour } \\
\text { (AWU) }\end{array}$ & $\begin{array}{c}\mathbf{2 0 1 0 / 2 0 0 7} \\
\text { SO } \\
\text { (Euro) }\end{array}$ & $\begin{array}{c}\text { No of } \\
\text { Farms }\end{array}$ & $\begin{array}{c}\text { Labour } \\
\text { (AWU) }\end{array}$ & $\begin{array}{c}\mathbf{2 0 1 3 / 2 0 1 0} \\
\text { SO * } \\
\text { (Euro) }\end{array}$ & $\begin{array}{c}\text { No of } \\
\text { Farms }\end{array}$ \\
\hline Bulgaria & 78.5 & 94.7 & 92.2 & 80.1 & 98.8 & 74.5 & 76.2 & 119.5 & 68.0 \\
Czechia & 93.3 & 98.8 & 92.5 & 69.3 & 101.1 & 54.3 & 109.1 & 122.1 & 118.0 \\
Estonia & 83.3 & 91.7 & 81.5 & 69.2 & 110.8 & 81.7 & 77.2 & 98.8 & 94.4 \\
Latvia & 75.3 & 102.7 & 83.4 & 81.0 & 126.5 & 76.6 & 97.0 & 134.0 & 98.3 \\
Lithuania & 79.6 & 79.8 & 91.0 & 80.7 & 116.5 & 86.7 & 100.3 & 127.9 & 85.9 \\
Hungary & 86.4 & 89.2 & 87.5 & 106.1 & 124.3 & 91.8 & 99.6 & 103.1 & 85.0 \\
Poland & 100.0 & 106.1 & 96.5 & 83.3 & 110.4 & 62.9 & 101.6 & 115.9 & 94.9 \\
Romania & 85.0 & 95.2 & 92.3 & 70.8 & 89.8 & 97.8 & 97.2 & 114.6 & 94.1 \\
Slovenia & 88.3 & 105.6 & 97.6 & 90.9 & 103.8 & 99.0 & 109.1 & 110.6 & 97.0 \\
Slovakia & 96.1 & 105.1 & 100.4 & 41.1 & 130.0 & 33.1 & 88.9 & 93.2 & 93.8 \\
\hline
\end{tabular}

* The standard output of an agricultural product (crop or livestock) is the average monetary value of the agricultural output at farm-gate price, in Euro per hectare or per head of livestock. Source: Authors calculations based on Eurostat.

In general (with a few exceptions), labour input and the number of farms decreased and the standard output (SO) increased. Later on, in 2013, in comparison with 2010, labour use stabilised or increased with the exception of Bulgaria, Estonia, and Slovakia. Initially, the main drop in the number of farms was due to the disappearance of the smallest ones with land area up to 2 hectares (ha). Two countries with a large number of small farms, Bulgaria and Romania, showed different speed of restructuring-a quick disappearance of the smallest farms in Bulgaria, but slow in Romania which, in the first years post-accession, e.g., in 2010, ended up with 2.7 million farms smaller than 2 ha, amounting to $70.8 \%$ of all farms. The decrease of labour used, increase of standard output, and disappearance of the smallest farms boosted labour productivity, measured as standard output per AWU, in all countries albeit with a different rate, is given in Table 3.

Table 3. Standard output per AWU (Euro).

\begin{tabular}{ccccc}
\hline Country & $\mathbf{2 0 0 5}$ & $\mathbf{2 0 0 7}$ & $\mathbf{2 0 1 0}$ & $\mathbf{2 0 1 3}$ \\
\hline Bulgaria & 2703 & 3260 & 4021 & 6309 \\
Czechia & 17,623 & 18,659 & 27,235 & 30,491 \\
Estonia & 7916 & 8717 & 13,946 & 17,859 \\
Latvia & 3543 & 4828 & 7543 & 10,421 \\
Lithuania & 6241 & 6250 & 9021 & 11,499 \\
Hungary & 6297 & 6501 & 7615 & 7881 \\
Poland & 6555 & 6961 & 9227 & 10,527 \\
Romania & 3425 & 3840 & 4870 & 5740 \\
Slovenia & 8177 & 9778 & 11,168 & 11,330 \\
Slovakia & 5606 & 6130 & 19,382 & 20,329 \\
\hline
\end{tabular}

Source: Authors calculations based on Eurostat.

The competitive pressure in the EU Single Market contributed to the dynamic changes in the number and size of farm units, labour, and output.

Based on the above background, it is important to identify the drivers of the structural change during the first decade of EU membership and implementation of the CAP, i.e., the extent to which it has been technology or endowment driven, and to understand the changing dynamics in different countries which may affect their competitiveness within the EU. For this purpose, we employ the Oaxaca-Blinder technique [6,7].

\section{Methodological Approach}

Structural change can be studied at different level of aggregation, and, in this paper, a micro approach is taken to analyse structural change at a farm level. The main assumption is that farms are heterogenous; thus, they may react differently to the drivers of structural change. Often, this heterogeneity is explained with path dependency [13]. 
We apply the most widely used version of the Oaxaca-Blinder decomposition for linear regression models with a dependent variable $y$ and regressors collected in a design matrix X. The representation is as follows (we follow Reference [14], who provides an excellent overview of the underlying issues):

$$
\Delta \bar{y}=\bar{X}_{1}^{\prime} \hat{\beta_{1}}-\bar{X}_{0}{ }^{\prime} \hat{\beta_{0}}=\left(\bar{X}_{1}-\bar{X}_{0}\right)^{\prime} \hat{\beta_{0}}+\bar{X}_{0}{ }^{\prime}\left(\hat{\beta_{1}}-\hat{\beta_{0}}\right)+\left(\bar{X}_{1}-\bar{X}_{0}\right)^{\prime}\left(\hat{\beta_{1}}-\hat{\beta_{0}}\right),
$$

where hats signify estimated quantities (the coefficients), bars show mean values, and the subscripts 1 and 0 refer to the corresponding samples. In our case, these are the two time points, i.e., 2007 and 2015. In the case of output changes over a given period, the above decomposes the difference between the mean output between the two time points (i.e., $\Delta \bar{y}$ ) as a sum of three distinct components. By explaining the output in each separate time point by a different regression function and constructing the difference between these two different regressions for each time period (i.e., $\left.\Delta \bar{y}=\bar{X}_{1}^{\prime} \hat{\beta}_{1}-\bar{X}_{0}^{\prime} \hat{\beta}_{0}\right)$ ), the above difference is restated as a decomposition into effect of endowment, technological change, and interaction of the two.

More specifically, the first term in this decomposition $\left(\bar{X}_{1}-\bar{X}_{0}\right)^{\prime} \hat{\beta}_{0}$ is the 'endowment' effect. It measures the effect on the final change of output that is due to the change in the 'endowments', in this case, the available factors of production land, labour, capital, and intermediate consumption, i.e., $\left(\bar{X}_{1}-\bar{X}_{0}\right)$, weighted by the initial relationship, i.e., the production technology at the start of the period, represented by the coefficients of the production function in the first time point $\hat{\beta_{0}}$. Therefore, the endowment effect measures what the output effect of the change in the endowment would have been if the production technology was kept constant.

The second term $\bar{X}_{0}{ }^{\prime}\left(\hat{\beta_{1}}-\hat{\beta_{0}}\right)$ is the effect of the coefficients. It represents the effect of the change in the regression coefficients between the two time points, i.e., the change in the production technology, evaluated at (i.e., weighted by) the initial endowment. Similarly to the endowment effect, the interpretation of this one is the output change that would have resulted from the technological change (i.e., change in the production function between the two time points), if endowments themselves did not change. The last term is essentially an interaction of endowment and technology changes.

To obtain the above decomposition, one needs to estimate the corresponding regression coefficients for each time point (i.e., $\hat{\beta_{1}}$ and $\hat{\beta_{0}}$ ) and then calculate the corresponding terms in the decomposition. Since this is a two-step procedure, standard asymptotics do not hold, and the relevant sampling distributions of these effects are obtained by bootstrapping both steps. Here, we have used 10,000 bootstrap replications and calculated the approximate bootstrap standard errors. The above procedure was repeated for all ten countries.

\section{Data}

We have used the FADN datasets for 2007 and 2015 for all ten countries considered in this paper. In order to construct the Oaxaca-Blinder decomposition, we have employed a standard translog production function specification in which the total farm output is explained by four production factors, namely capital, labour, land, and intermediate consumption. Hence, the data includes measures of these five variables over the two time points (2007 and 2015), which define the period over which the corresponding output changes are being investigated. The translog specification is linear in parameters (although not in the production inputs); thus, the standard linear regression approach outlined above is applicable to the transformed version of the data that includes logarithms and logarithmic interactions.

Concerning the variables, we use the monetary value of farm output in Euro, the capital measured as the total value of assets minus the land value in Euro, labour represented as the total labour input in AWU, land measured in hectares, and the value of intermediate consumption in Euro. The latter is included since some farms may produce an intermediate product which they do not sell but use as an input for their final output, e.g., a farm may 
grow maize to use as animal feed. Additionally, the family labour (classified as unpaid in FADN) in AWU was used to distinguish family farms from the rest of farm units and, thus, was not included in the production function specification but used as a filter.

Using nominal monetary values directly for both time points would also reflect inflationary pressure; therefore, we deflated the monetary values for 2015 using 2007 as a base year for output, capital, and intermediate consumption. A standard way of doing this is by dividing the 2015 monetary values by a deflator for the period. In principle, agricultural producer price index would have been the most relevant deflator but it was not available for the studied countries. For this reason, we used the World Bank GDP deflator and aggregated the annual indices over the period to calculate an overall deflator for each country. There is an additional consideration to take into account, i.e., that the monetary data in FADN is in Euros and changes in the Euro exchange rate to national currencies create an effect similar to that of inflation. We have, therefore, additionally deflated the monetary values by an exchange rate change index with regard to the 2007 values similarly to the way we did with the inflation changes. This mainly affects countries which did not join the Eurozone-Czechia, Hungary, Poland, and Romania. Slovenia used the Euro throughout the analysed period, while Bulgaria's currency board effectively fixed its national currency against the Euro. The remaining NMS joined the Eurozone at different years during the period under investigation. However, since, before joining the Euro, they were part of the European exchange rate mechanism, their currencies were closely linked to the Euro and could only fluctuate within a small margin. For this reason, the European Central Bank reports their reference exchange rates for the period as the one they used when joining the Eurozone. Therefore, it was not necessary to introduce exchange rate adjustments for these countries.

Before proceeding to our decomposition results, it would be useful to describe the family sector with regard to the rest of agriculture and to present its development over the studied period. We first look at the mean values of the output in each country for family and non-family farms. This comparison places the family sector within the more general farm structure of each country. Due to the focus of this paper on structural change in the family farm sector, family farms are the part of the FADN sample used to estimate the relevant decomposition, with the rest of the FADN sample, which includes the non-family farms (defined in this paper as farms employing less than 1 AWU family labour), presented in Table 4 for comparison purposes only.

Table 4. Comparison of average output changes in family and non-family farms, 2007-2015.

\begin{tabular}{ccccccc}
\hline & \multicolumn{2}{c}{ Family Farms } & \multicolumn{3}{c}{ Non-Family Farms } \\
& $\mathbf{2 0 0 7}$ & $\mathbf{2 0 1 5}$ & Change & $\mathbf{2 0 0 7}$ & $\mathbf{2 0 1 5}$ & $\begin{array}{c}\text { Change } \\
\text { (\%) }\end{array}$ \\
& $\mathbf{( E u r o )}$ & $\mathbf{( E u r o )}$ & $\mathbf{( \% )}$ & $\mathbf{( E u r o )}$ & $\mathbf{( E u r o )}$ & $57 \%$ \\
\hline Bulgaria & 18,091 & 22,568 & $25 \%$ & 42,767 & 67,113 & $-2 \%$ \\
Czechia & 82,259 & 73,040 & $-11 \%$ & 947,453 & 927,936 & $-56 \%$ \\
Estonia & 49,447 & 42,934 & $-13 \%$ & 184,031 & 81,011 & $-27 \%$ \\
Hungary & 73,971 & 73,038 & $-1 \%$ & 71,902 & 52,441 & $53 \%$ \\
Lithuania & 39,381 & 45,828 & $16 \%$ & 145,415 & 223,109 & $-25 \%$ \\
Latvia & 43,536 & 48,360 & $11 \%$ & 190,954 & 143,789 & $9 \%$ \\
Poland & 32,920 & 31,641 & $-4 \%$ & 24,930 & 27,168 & $-85 \%$ \\
Romania & 10,067 & 14,878 & $48 \%$ & 130,070 & 19,942 & $-45 \%$ \\
Slovakia & 97,549 & 119,642 & $23 \%$ & $1,023,009$ & 558,929 & $-4 \%$ \\
Slovenia & 32,388 & 27,073 & $-16 \%$ & 11,109 & 10,637 & \\
\hline Source: authors calculation using transformed FADN data. & & &
\end{tabular}

Table 4 shows that, with the exception of Hungary, Poland, and Slovenia, family farms were smaller in terms of output compared to the rest of agriculture. The initial conditions should be taken into account here. As mentioned previously, in Poland and Slovenia independent farmers were predominant before the reforms, whilst Hungary has started implementing some elements of market economy as early as 1960s. However, in Poland, in 
both time points, and, in Hungary, in 2015, the difference in output between the two types of farm organisation was relatively small. However, looking at the underlying factors of production, in particular, labour and capital (presented in Appendix A), the family farms in Poland and Hungary have been indeed larger than the rest.

In terms of relative growth of the two types, the picture is more diverse. The output of the average family farm has increased in the period 2007-2015, with the exception of Czechia, Estonia, and Slovenia. In Poland and Hungary, it contracted, as well, but by a very small percentage. However, looking at the non-family category, its output has decreased across the board, with the exception of Bulgaria, Lithuania, and Poland. This means that, although, in general, the family farms might be smaller than the rest, post-accession to the $\mathrm{EU}$, and after the implementation of the CAP support, they have started closing the gap.

Romania and Bulgaria experienced a larger increase of family farms output than the remaining NMS. It is important to note a qualitative difference between Bulgaria and Romania, which joined the EU in 2007, whilst the remaining CEECs joined at 2004, and, by 2007, they had three years of EU membership — a period of major adjustments when much of the output gains might have been made. Slovakia also experienced increases comparable in relative terms to that of Bulgaria. Much of this family farms output increase in Slovakia has been probably due to rebalancing between the two sectors since, over the period under consideration, the average output in the non-family farms has reduced dramatically.

In summary, the differences in the initial conditions, the farms structures emerging from the post-communist land reforms, and the adjustments to the CAP have brought about quite a diverse picture concerning the changes in output in the family farms compared to the general farm structure in each NMS. The a priori expected dynamics of positive output growth in family farms and negative in the non-family sector has only materialised in Latvia, Romania, and Slovakia. The second group includes countries which recorded positive growth in both types of farm organisation, i.e., Bulgaria and Lithuania. The third group experienced contraction in both sectors-Czechia, Estonia, Hungary, and Slovenia, although the magnitude of the decrease in relative terms in non-family output in Czechia has been negligible. Poland has recorded a decrease in family farms output and increase in non-family but both by less than $10 \%$.

\section{Decomposition Results}

Our estimated decomposition of the output changes is presented in Table 5. Since the regression model used to construct these decompositions is based on a translog specification, the dependent variable is not output itself but its natural logarithm. If we denote output by $Y$, then, the change being decomposed is essentially $\log \left(Y_{2015}\right)-\log \left(Y_{2007}\right)=\log \left(\frac{Y_{2015}}{Y_{2007}}\right)$. Therefore, the estimated decomposition is applied to the relative change in output. This has two useful consequences. First, the sign of the changes can be interpreted in the usual way (positive sign denoting increase and negative one-decrease), and, second, since these are relative changes, they can be directly compared across countries. For completeness the raw regressions for 2007 and 2015 used to construct the above decomposition (after they are simultaneously bootstrapped), which are presented in Appendix B.

Almost all countries show that the model coefficients, i.e., technological change, provide a significant effect. In simple terms, this demonstrates a shift in the family farms production function, with the exception of only Lithuania and Slovakia, where the corresponding technological change effects are not statistically significant. Consequently, it appears that across the board the production technology shift has been a driving force of the structural change in the CEECs family farms. However, a closer look at the sign, i.e., the direction of technological change effects, reveals differences between countries. While this effect is positive for the countries that acceded to the EU in 2007, Bulgaria and Romania, it is positive for only one of the countries that joined in 2004, namely Latvia. For all other seven NMS that joined in 2004, the technological changes either had a negative effect on family farms output or, as in the case of Lithuania and Slovakia, no significant effect. This suggests the possibility of a rapid technical change in family farms in the early 
years of EU accession, followed by slowing down when they are overtaken by the rest of the agricultural sector. This is an issue that deserves more detailed consideration in future research investigating a longer time period.

Table 5. Estimated decomposition of output changes.

\begin{tabular}{lccccccc}
\hline & Endowments & SE & $\begin{array}{c}\text { Technological } \\
\text { Change }\end{array}$ & SE & Interaction & SE & Total \\
\hline Bulgaria & 0.039 & 0.065 & $\mathbf{0 . 1 7 3}$ & $\mathbf{0 . 0 5 0}$ & 0.009 & 0.042 & 0.221 \\
Czechia & -0.006 & 0.050 & $\mathbf{- 0 . 1 4 7}$ & $\mathbf{0 . 0 2 9}$ & 0.034 & 0.026 & -0.119 \\
Estonia & 0.008 & 0.130 & $\mathbf{- 0 . 1 7 3}$ & $\mathbf{0 . 0 4 8}$ & 0.023 & 0.080 & -0.141 \\
Hungary & $\mathbf{0 . 1 1 8}$ & $\mathbf{0 . 0 5 0}$ & $\mathbf{- 0 . 1 3 9}$ & $\mathbf{0 . 0 3 3}$ & $\mathbf{0 . 0 0 8}$ & $\mathbf{0 . 0 1 9}$ & -0.013 \\
Lithuania & $\mathbf{0 . 1 2 9}$ & $\mathbf{0 . 0 5 6}$ & 0.006 & 0.026 & 0.017 & 0.017 & 0.152 \\
Latvia & -0.065 & 0.058 & $\mathbf{0 . 1 6 4}$ & $\mathbf{0 . 0 2 6}$ & 0.007 & 0.022 & 0.105 \\
Poland & $\mathbf{0 . 1 0 8}$ & $\mathbf{0 . 0 1 1}$ & $\mathbf{- 0 . 1 5 7}$ & $\mathbf{0 . 0 0 8}$ & 0.009 & 0.006 & -0.040 \\
Romania & $\mathbf{0 . 2 5 8}$ & $\mathbf{0 . 0 8 1}$ & $\mathbf{0 . 1 7 1}$ & $\mathbf{0 . 0 7 2}$ & -0.039 & 0.072 & 0.391 \\
Slovakia & -0.063 & 0.120 & -0.028 & 0.073 & $-\mathbf{0 . 1 1 4}$ & $\mathbf{0 . 0 7 5}$ & -0.204 \\
Slovenia & $\mathbf{0 . 1 5 6}$ & $\mathbf{0 . 0 7 1}$ & $\mathbf{0 . 0 9 0}$ & $\mathbf{0 . 0 4 2}$ & -0.066 & 0.061 & 0.179 \\
\hline Significant
\end{tabular}

Significant components in bold.

The change in endowments is also an important contributor in five out of the ten countries, while the interaction of endowment and technological change is a significant driver of the changes in only two countries. The effect of endowments is mostly positive, with the only exception being Slovenia. This suggests that the family farming sector grows by accumulating productive resources. However, this growth has not always materialised in family farms output. In Bulgaria, Czechia, Latvia, Estonia, and Slovakia, this accumulation of productive resources has not been translated in output growth. What this means is not that such growth has not taken place. Indeed, a closer look at the changes in endowments presented in Appendix A reveals that the family sector has increased its endowments, particularly capital and land. This growth has not, however, for the aforementioned countries, been translated into output growth.

If we take the relative share of the technological shift in the explained changes, then, in four countries (Bulgaria, Czechia, Latvia, and Estonia), it is the only significant change, thus accounting for all of the changes in family farms output. Romania and Slovenia show both endowments and technological change effects, with endowment accounting for about $60 \%$ of the changes. Note, however, that the underlying dynamics in these two countries is quite different-growth of family farming in Romania and contraction in Slovenia. Poland and Hungary, which are two countries which started their transition earlier than the rest of Central and Eastern Europe and required less adjustments of farm structures to a market economy, show a very different de-compositional pattern. In both countries, the changes in endowments increase the family farms output. However, this increase is more than offset by productivity losses due to technological change, hence resulting in contraction of the output of the family farming sector. This may suggest that, while, in the early stages of transition (exemplified here by Bulgaria and Romania), the family sector benefits from technological change, later in transition, as in Hungary and Poland, it faces technological constraints and the accumulation of resources becomes its main source of growth. It may be that such resource accumulation is a precursor necessary to initiate a next cycle of technological gains, but this is a process that might need longer time to materialise.

Finally, the only driver of family farming changes in Slovakia is the interaction between endowments and technological changes, while, in Lithuania, endowments account for most of the changes with a small contribution from the interaction.

\section{Conclusions}

This paper studied the sources of agricultural output changes in family farms in the CEECs. We have discovered several commonalities in the development of the family farming in these countries but also distinct differences. While some of these differences 
may be attributed to different initial conditions, taking into account the differences in the history of transition and post-communist reforms, the timing of accession to the EU allows us to group these changes into several underlying trends. In particular, our analysis suggests that the early stages of EU accession appear to benefit family farms in terms of accelerated technological change, which becomes the main source of productivity gains. Later on, the productivity gains generated by the technological change disappear and even reverse, indicating that family farming reaches growth constraints. However, as the agricultural economy further develops, taking advantage of the support measures of the EU CAP, the endowment effect appears, and growth due to the accumulation of productive resources takes place. This growth may start to bridge the gap due to the lack of technological advancement, and it is not inconceivable to expect that it may lead to a next stage of output growth when these endowments effects would facilitate a new wave of technological change.

Author Contributions: Conceptualization, P.K. and S.D.; Methodology, P.K.; Formal analysis, P.K.; Investigation P.K. and S.D.; Writing—original draft preparation, S.D.; Writing—review and editing, P.K. and S.D. All authors have read and agreed to the published version of the manuscript.

Funding: This research received no external funding.

Data Availability Statement: Not applicable.

Conflicts of Interest: The authors declare no conflict of interest.

\section{Appendix A. Summary Statistics}

Table A1. Changes in factors of production in family and non-family farms, 2007-2015.

\begin{tabular}{|c|c|c|c|c|c|c|c|}
\hline & & $\begin{array}{c}\text { Family } \\
\text { Farms } 2007\end{array}$ & $\begin{array}{c}\text { Family } \\
\text { Farms } 2015\end{array}$ & Growth & $\begin{array}{c}\text { Non-Family } \\
\text { Farms } 2007\end{array}$ & $\begin{array}{c}\text { Non_Family } \\
\text { Farms } 2015\end{array}$ & Growth \\
\hline \multirow[t]{4}{*}{ Bulgaria } & capital & 7297 & 10,235 & $40 \%$ & 9667 & 22,089 & $129 \%$ \\
\hline & labour & 2.90 & 2.59 & $-11 \%$ & 4.56 & 3.98 & $-13 \%$ \\
\hline & land & 6.84 & 8.14 & $19 \%$ & 24.55 & 37.75 & $54 \%$ \\
\hline & ic & 8858 & 7602 & $-14 \%$ & 19,606 & 31,851 & $62 \%$ \\
\hline \multirow[t]{4}{*}{ Czech Republic } & capital & 91,668 & 101,569 & $11 \%$ & $1,315,087$ & 718,893 & $-45 \%$ \\
\hline & labour & 2.27 & 2.31 & $2 \%$ & 25.76 & 17.49 & $-32 \%$ \\
\hline & land & 62.40 & 55.42 & $-11 \%$ & 654.88 & 559.38 & $-15 \%$ \\
\hline & ic & 40,752 & 41,982 & $3 \%$ & 620,832 & 684,973 & $10 \%$ \\
\hline \multirow[t]{4}{*}{ Estonia } & capital & 56,951 & 60,313 & $6 \%$ & 159,742 & 83,904 & $-47 \%$ \\
\hline & labour & 2.08 & 1.72 & $-17 \%$ & 5.36 & 1.88 & $-65 \%$ \\
\hline & land & 101.85 & 79.61 & $-22 \%$ & 146.72 & 91.97 & $-37 \%$ \\
\hline & ic & 25,025 & 31,452 & $26 \%$ & 86,297 & 60,716 & $-30 \%$ \\
\hline \multirow[t]{4}{*}{ Hungary } & capital & 55,953 & 72,807 & $30 \%$ & 35,672 & 28,608 & $-20 \%$ \\
\hline & labour & 2.20 & 2.53 & $15 \%$ & 1.76 & 1.60 & $-9 \%$ \\
\hline & land & 54.31 & 47.73 & $-12 \%$ & 53.94 & 37.45 & $-31 \%$ \\
\hline & ic & 47,333 & 63,381 & $34 \%$ & 52,098 & 51,493 & $-1 \%$ \\
\hline \multirow[t]{4}{*}{ Lithuania } & capital & 44,162 & 43,689 & $-1 \%$ & 127,487 & 188,256 & $48 \%$ \\
\hline & labour & 2.04 & 2.01 & $-1 \%$ & 4.39 & 4.39 & $0 \%$ \\
\hline & land & 61.33 & 65.21 & $6 \%$ & 159.44 & 213.72 & $34 \%$ \\
\hline & ic & 37,270 & 47,968 & $29 \%$ & 130,831 & 211,201 & $61 \%$ \\
\hline \multirow[t]{4}{*}{ Latvia } & capital & 33,215 & 35,540 & $7 \%$ & 116,841 & 93,066 & $-20 \%$ \\
\hline & labour & 2.29 & 1.92 & $-16 \%$ & 7.56 & 3.83 & $-49 \%$ \\
\hline & land & 76.34 & 76.69 & $0 \%$ & 185.06 & 155.93 & $-16 \%$ \\
\hline & ic & 33,786 & 30,767 & $-9 \%$ & 130,183 & 98,262 & $-25 \%$ \\
\hline \multirow[t]{3}{*}{ Poland } & capital & 65,553 & 82,291 & $26 \%$ & 38,643 & 50,836 & $32 \%$ \\
\hline & labour & 1.93 & 1.85 & $-4 \%$ & 1.30 & 1.43 & $9 \%$ \\
\hline & land & 20.80 & 25.18 & $21 \%$ & 20.45 & 29.29 & $43 \%$ \\
\hline
\end{tabular}


Table A1. Cont.

\begin{tabular}{|c|c|c|c|c|c|c|c|}
\hline & & $\begin{array}{c}\text { Family } \\
\text { Farms } 2007\end{array}$ & $\begin{array}{c}\text { Family } \\
\text { Farms } 2015\end{array}$ & Growth & $\begin{array}{l}\text { Non-Family } \\
\text { Farms } 2007\end{array}$ & $\begin{array}{c}\text { Non_Family } \\
\text { Farms } 2015\end{array}$ & Growth \\
\hline & ic & 16,855 & 19,574 & $16 \%$ & 13,212 & 19,094 & $45 \%$ \\
\hline \multirow[t]{4}{*}{ Romania } & capital & 8325 & 19,632 & $136 \%$ & 65,223 & 30,108 & $-54 \%$ \\
\hline & labour & 2.43 & 1.79 & $-26 \%$ & 8.53 & 1.38 & $-84 \%$ \\
\hline & land & 6.25 & 12.30 & $97 \%$ & 57.07 & 20.23 & $-65 \%$ \\
\hline & ic & 3655 & 4527 & $24 \%$ & 50,389 & 6170 & $-88 \%$ \\
\hline \multirow[t]{4}{*}{ Slovakia } & capital & 31,359 & 47,654 & $52 \%$ & $1,648,759$ & 273,442 & $-83 \%$ \\
\hline & labour & 3.31 & 2.67 & $-19 \%$ & 40.47 & 12.28 & $-70 \%$ \\
\hline & land & 140.09 & 144.89 & $3 \%$ & $1,166.46$ & 615.34 & $-47 \%$ \\
\hline & ic & 54,862 & 79,165 & $44 \%$ & 689,759 & 400,049 & $-42 \%$ \\
\hline \multirow[t]{4}{*}{ Slovenia } & capital & 89,070 & 85,254 & $-4 \%$ & 32,346 & 38,279 & $18 \%$ \\
\hline & labour & 2.10 & 1.69 & $-19 \%$ & 0.70 & 0.65 & $-7 \%$ \\
\hline & land & 15.79 & 11.99 & $-24 \%$ & 7.96 & 7.43 & $-7 \%$ \\
\hline & ic & 12,893 & 19,084 & $48 \%$ & 3656 & 8641 & $136 \%$ \\
\hline
\end{tabular}

Appendix B. Individual Regressions for Base and Reference Year per Country (Variables in Logarithms)

Table A2. Bulgaria 2007.

\begin{tabular}{ccccc}
\hline & Estimate & SE & T Statistic & $p$-Value \\
\hline (Intercept $)$ & 6.096 & 0.402 & 15.166 & 0.000 \\
capital & -0.050 & 0.049 & -1.013 & 0.311 \\
labour & 1.275 & 0.197 & 6.486 & 0.000 \\
land & 0.320 & 0.084 & 3.799 & 0.000 \\
ic & -0.007 & 0.062 & -0.113 & 0.910 \\
$\mathrm{I}\left(0.5^{*}\right.$ capital^2) & 0.039 & 0.005 & 7.292 & 0.000 \\
$\mathrm{I}\left(0.5^{*}\right.$ labour2 $)$ & 0.142 & 0.076 & 1.874 & 0.061 \\
$\mathrm{I}\left(0.5^{*}\right.$ land^2) & 0.078 & 0.013 & 5.997 & 0.000 \\
$\mathrm{I}\left(0.5^{*}\right.$ ic^2) & 0.065 & 0.007 & 8.983 & 0.000 \\
capital:labour & -0.003 & 0.014 & -0.187 & 0.851 \\
capital:land & -0.010 & 0.007 & -1.527 & 0.127 \\
capital:ic & -0.013 & 0.005 & -2.456 & 0.014 \\
labour:land & -0.061 & 0.019 & -3.250 & 0.001 \\
labour:ic & -0.076 & 0.024 & -3.191 & 0.001 \\
land:ic & -0.021 & 0.010 & -2.221 & 0.027 \\
\hline
\end{tabular}

Table A3. Bulgaria 2015.

\begin{tabular}{ccccc}
\hline & Estimate & SE & T Statistic & $p$-Value \\
\hline (Intercept) & 7.139 & 0.331 & 21.538 & 0.000 \\
capital & -0.049 & 0.046 & -1.073 & 0.283 \\
labour & 1.305 & 0.196 & 6.645 & 0.000 \\
land & 0.401 & 0.059 & 6.845 & 0.000 \\
ic & -0.147 & 0.047 & -3.107 & 0.002 \\
$\mathrm{I}\left(0.5^{*}\right.$ capital`2) & 0.048 & 0.005 & 9.275 & 0.000 \\
$\mathrm{I}\left(0.5^{*}\right.$ labour^2) & 0.121 & 0.083 & 1.461 & 0.144 \\
$\mathrm{I}\left(0.5^{*}\right.$ land² $)$ & 0.152 & 0.014 & 10.994 & 0.000 \\
$\mathrm{I}\left(0.5^{*}\right.$ ic^2) & 0.055 & 0.005 & 11.583 & 0.000 \\
capital:labour & -0.064 & 0.021 & -3.048 & 0.002 \\
capital:land & -0.021 & 0.006 & -3.563 & 0.000 \\
capital:ic & -0.011 & 0.005 & -2.242 & 0.025 \\
labour:land & -0.103 & 0.018 & -5.803 & 0.000 \\
labour:ic & 0.010 & 0.018 & 0.559 & 0.576 \\
land:ic & -0.029 & 0.006 & -5.029 & 0.000 \\
\hline
\end{tabular}


Table A4. Czech Republic 2007.

\begin{tabular}{ccccc}
\hline & Estimate & SE & T Statistic & $p$-Value \\
\hline (Intercept $)$ & 13.419 & 1.116 & 12.028 & 0.000 \\
capital & -0.164 & 0.104 & -1.567 & 0.118 \\
labour & 1.531 & 0.489 & 3.133 & 0.002 \\
land & 0.892 & 0.181 & 4.919 & 0.000 \\
ic & -1.309 & 0.250 & -5.234 & 0.000 \\
$\mathrm{I}\left(0.5^{*}\right.$ capital`2) & 0.027 & 0.007 & 3.709 & 0.000 \\
$\mathrm{I}\left(0.5^{*}\right.$ labour^2) & -0.052 & 0.096 & -0.541 & 0.589 \\
$\mathrm{I}\left(0.5^{*}\right.$ land² $)$ & 0.128 & 0.013 & 9.616 & 0.000 \\
$\mathrm{I}\left(0.5^{*}\right.$ ic^2) & 0.179 & 0.031 & 5.830 & 0.000 \\
capital:labour & 0.026 & 0.035 & 0.753 & 0.452 \\
capital:land & -0.034 & 0.013 & -2.726 & 0.007 \\
capital:ic & 0.009 & 0.010 & 0.886 & 0.376 \\
labour:land & -0.025 & 0.029 & -0.882 & 0.378 \\
labour:ic & -0.119 & 0.046 & -2.591 & 0.010 \\
land:ic & -0.067 & 0.016 & -4.099 & 0.000 \\
\hline
\end{tabular}

Table A5. Czech republic 2015.

\begin{tabular}{ccccc}
\hline & Estimate & SE & T Statistic & $p$-Value \\
\hline (Intercept $)$ & 11.365 & 1.936 & 5.871 & 0.000 \\
capital & -0.545 & 0.225 & -2.426 & 0.016 \\
labour & 2.636 & 0.557 & 4.729 & 0.000 \\
land & 0.610 & 0.219 & 2.783 & 0.006 \\
ic & -0.473 & 0.224 & -2.115 & 0.035 \\
$\mathrm{I}\left(0.5^{*}\right.$ capital`2) & -0.001 & 0.020 & -0.036 & 0.971 \\
$\mathrm{I}\left(0.5^{*}\right.$ labour^2) & 0.304 & 0.114 & 2.653 & 0.008 \\
$\mathrm{I}\left(0.5^{*}\right.$ land²) & 0.197 & 0.019 & 10.493 & 0.000 \\
$\mathrm{I}\left(0.5^{*}\right.$ ic²) & 0.043 & 0.012 & 3.723 & 0.000 \\
capital:labour & -0.059 & 0.047 & -1.249 & 0.212 \\
capital:land & -0.009 & 0.020 & -0.474 & 0.636 \\
capital:ic & 0.066 & 0.025 & 2.709 & 0.007 \\
labour:land & -0.107 & 0.034 & -3.186 & 0.002 \\
labour:ic & -0.113 & 0.040 & -2.856 & 0.004 \\
land:ic & -0.083 & 0.017 & -4.913 & 0.000 \\
\hline
\end{tabular}

Table A6. Estonia 2007.

\begin{tabular}{ccccc}
\hline & Estimate & SE & T Statistic & $p$-Value \\
\hline (Intercept $)$ & 8.458 & 0.649 & 13.037 & 0.000 \\
capital & -0.225 & 0.082 & -2.731 & 0.007 \\
labour & 1.351 & 0.440 & 3.072 & 0.002 \\
land & -0.418 & 0.250 & -1.671 & 0.096 \\
ic & -0.077 & 0.079 & -0.968 & 0.334 \\
$\mathrm{I}\left(0.5^{*}\right.$ capital^2) & 0.021 & 0.009 & 2.358 & 0.019 \\
$\mathrm{I}\left(0.5^{*}\right.$ labour2 $)$ & 0.191 & 0.150 & 1.273 & 0.204 \\
$\mathrm{I}\left(0.5^{*}\right.$ land^2) & 0.015 & 0.036 & 0.428 & 0.669 \\
$\mathrm{I}\left(0.5^{*}\right.$ ic^2) & 0.064 & 0.015 & 4.420 & 0.000 \\
capital:labour & 0.061 & 0.055 & 1.110 & 0.268 \\
capital:land & 0.061 & 0.029 & 2.108 & 0.036 \\
capital:ic & -0.005 & 0.007 & -0.627 & 0.531 \\
labour:land & -0.184 & 0.085 & -2.156 & 0.032 \\
labour:ic & -0.105 & 0.055 & -1.914 & 0.056 \\
land:ic & -0.001 & 0.032 & -0.032 & 0.974 \\
\hline
\end{tabular}


Table A7. Estonia 2015.

\begin{tabular}{ccccc}
\hline & Estimate & SE & T Statistic & $p$-Value \\
\hline (Intercept $)$ & 2.477 & 3.556 & 0.696 & 0.487 \\
capital & -0.035 & 0.449 & -0.078 & 0.938 \\
labour & 1.387 & 1.263 & 1.098 & 0.273 \\
land & -1.090 & 0.693 & -1.572 & 0.117 \\
ic & 1.162 & 0.738 & 1.573 & 0.117 \\
$\mathrm{I}\left(0.5^{*}\right.$ capital`2) & 0.085 & 0.049 & 1.713 & 0.088 \\
$\mathrm{I}\left(0.5^{*}\right.$ labour^2) & 0.202 & 0.258 & 0.783 & 0.435 \\
$\mathrm{I}\left(0.5^{*}\right.$ land² $)$ & 0.111 & 0.083 & 1.337 & 0.183 \\
$\mathrm{I}\left(0.5^{*}\right.$ ic^2) & -0.062 & 0.084 & -0.741 & 0.460 \\
capital:labour & 0.129 & 0.139 & 0.931 & 0.353 \\
capital:land & -0.014 & 0.060 & -0.239 & 0.811 \\
capital:ic & -0.055 & 0.041 & -1.345 & 0.180 \\
labour:land & -0.244 & 0.144 & -1.700 & 0.091 \\
labour:ic & -0.136 & 0.162 & -0.835 & 0.405 \\
land:ic & 0.111 & 0.082 & 1.352 & 0.178 \\
\hline
\end{tabular}

Table A8. Hungary 2007.

\begin{tabular}{ccccc}
\hline & Estimate & SE & T Statistic & $p$-Value \\
\hline (Intercept $)$ & 9.300 & 1.254 & 7.417 & 0.000 \\
capital & 0.026 & 0.114 & 0.225 & 0.822 \\
labour & 2.155 & 0.564 & 3.821 & 0.000 \\
land & 0.267 & 0.196 & 1.366 & 0.172 \\
ic & -0.676 & 0.274 & -2.471 & 0.014 \\
$\mathrm{I}\left(0.5^{*}\right.$ capital`2) & 0.051 & 0.008 & 6.494 & 0.000 \\
$\mathrm{I}\left(0.5^{*}\right.$ labour^2) & 0.192 & 0.136 & 1.412 & 0.158 \\
$\mathrm{I}\left(0.5^{*}\right.$ land²) & 0.158 & 0.020 & 8.099 & 0.000 \\
$\mathrm{I}\left(0.5^{*}\right.$ ic^2) & 0.154 & 0.035 & 4.410 & 0.000 \\
capital:labour & -0.107 & 0.042 & -2.565 & 0.011 \\
capital:land & -0.015 & 0.014 & -1.089 & 0.276 \\
capital:ic & -0.025 & 0.014 & -1.819 & 0.069 \\
labour:land & -0.011 & 0.036 & -0.319 & 0.750 \\
labour:ic & -0.070 & 0.058 & -1.210 & 0.227 \\
land:ic & -0.052 & 0.020 & -2.621 & 0.009 \\
\hline
\end{tabular}

Table A9. Hungary 2015.

\begin{tabular}{ccccc}
\hline & Estimate & SE & T Statistic & $p$-Value \\
\hline (Intercept) & 8.171 & 1.840 & 4.441 & 0.000 \\
capital & 0.012 & 0.188 & 0.063 & 0.950 \\
labour & 1.890 & 0.500 & 3.779 & 0.000 \\
land & 0.406 & 0.167 & 2.430 & 0.015 \\
ic & -0.379 & 0.270 & -1.403 & 0.161 \\
$\mathrm{I}\left(0.5^{*}\right.$ capital`2) & 0.046 & 0.008 & 5.639 & 0.000 \\
$\mathrm{I}\left(0.5^{*}\right.$ labour^2) & 0.207 & 0.116 & 1.778 & 0.076 \\
$\mathrm{I}\left(0.5^{*}\right.$ land² $)$ & 0.160 & 0.016 & 10.035 & 0.000 \\
$\mathrm{I}\left(0.5^{*}\right.$ ic^2) & 0.095 & 0.027 & 3.601 & 0.000 \\
capital:labour & -0.054 & 0.035 & -1.557 & 0.120 \\
capital:land & -0.020 & 0.012 & -1.667 & 0.096 \\
capital:ic & -0.016 & 0.018 & -0.865 & 0.387 \\
labour:land & -0.100 & 0.029 & -3.432 & 0.001 \\
labour:ic & -0.055 & 0.042 & -1.308 & 0.191 \\
land:ic & -0.048 & 0.015 & -3.152 & 0.002 \\
\hline
\end{tabular}


Table A10. Latvia 2007.

\begin{tabular}{ccccc}
\hline & Estimate & SE & T statistic & $p$-Value \\
\hline (Intercept $)$ & 3.554 & 1.070 & 3.321 & 0.001 \\
capital & 0.285 & 0.142 & 1.997 & 0.046 \\
labour & 0.355 & 0.329 & 1.077 & 0.282 \\
land & 0.090 & 0.213 & 0.421 & 0.674 \\
ic & 0.211 & 0.146 & 1.441 & 0.150 \\
$\mathrm{I}\left(0.5^{*}\right.$ capital`2) & 0.032 & 0.006 & 4.954 & 0.000 \\
$\mathrm{I}\left(0.5^{*}\right.$ labour^2) & 0.112 & 0.082 & 1.371 & 0.171 \\
$\mathrm{I}\left(0.5^{*}\right.$ land² $)$ & 0.071 & 0.032 & 2.228 & 0.026 \\
$\mathrm{I}\left(0.5^{*}\right.$ ic^2) & 0.084 & 0.012 & 7.294 & 0.000 \\
capital:labour & 0.067 & 0.028 & 2.397 & 0.017 \\
capital:land & 0.012 & 0.020 & 0.593 & 0.553 \\
capital:ic & -0.051 & 0.019 & -2.700 & 0.007 \\
labour:land & -0.154 & 0.036 & -4.314 & 0.000 \\
labour:ic & -0.024 & 0.043 & -0.562 & 0.574 \\
land:ic & -0.015 & 0.021 & -0.719 & 0.472 \\
\hline
\end{tabular}

Table A11. Latvia 2015.

\begin{tabular}{ccccc}
\hline & Estimate & SE & T Statistic & $p$-Value \\
\hline (Intercept $)$ & 7.441 & 0.604 & 12.320 & 0.000 \\
capital & -0.092 & 0.096 & -0.951 & 0.342 \\
labour & 0.904 & 0.292 & 3.096 & 0.002 \\
land & 0.683 & 0.198 & 3.446 & 0.001 \\
ic & -0.310 & 0.088 & -3.529 & 0.000 \\
$\mathrm{I}\left(0.5^{*}\right.$ capital`2) & 0.031 & 0.006 & 5.098 & 0.000 \\
$\mathrm{I}\left(0.5^{*}\right.$ labour^2) & 0.185 & 0.081 & 2.287 & 0.022 \\
$\mathrm{I}\left(0.5^{*}\right.$ land² $)$ & 0.310 & 0.040 & 7.723 & 0.000 \\
$\mathrm{I}\left(0.5^{*}\right.$ ic^2) & 0.101 & 0.012 & 8.128 & 0.000 \\
capital:labour & -0.014 & 0.027 & -0.518 & 0.605 \\
capital:land & -0.032 & 0.015 & -2.225 & 0.026 \\
capital:ic & 0.009 & 0.013 & 0.696 & 0.487 \\
labour:land & -0.109 & 0.040 & -2.732 & 0.006 \\
labour:ic & -0.012 & 0.033 & -0.376 & 0.707 \\
land:ic & -0.118 & 0.026 & -4.476 & 0.000 \\
\hline
\end{tabular}

Table A12. Lithuania 2007.

\begin{tabular}{ccccc}
\hline & Estimate & SE & T Statistic & $p$-Value \\
\hline (Intercept $)$ & 7.099 & 1.508 & 4.709 & 0.000 \\
capital & 0.393 & 0.210 & 1.877 & 0.061 \\
labour & 1.031 & 0.460 & 2.242 & 0.025 \\
land & 0.074 & 0.313 & 0.235 & 0.814 \\
ic & -0.590 & 0.321 & -1.837 & 0.067 \\
$\mathrm{I}\left(0.5^{*}\right.$ capital`2) & 0.028 & 0.009 & 3.196 & 0.001 \\
$\mathrm{I}\left(0.5^{*}\right.$ labour^2) & 0.085 & 0.110 & 0.774 & 0.439 \\
$\mathrm{I}\left(0.5^{*}\right.$ land² $)$ & 0.144 & 0.037 & 3.901 & 0.000 \\
$\mathrm{I}\left(0.5^{*}\right.$ ic^2) & 0.198 & 0.049 & 4.046 & 0.000 \\
capital:labour & 0.103 & 0.040 & 2.559 & 0.011 \\
capital:land & 0.045 & 0.025 & 1.775 & 0.076 \\
capital:ic & -0.071 & 0.029 & -2.466 & 0.014 \\
labour:land & -0.187 & 0.054 & -3.449 & 0.001 \\
labour:ic & -0.104 & 0.057 & -1.832 & 0.067 \\
land:ic & -0.065 & 0.035 & -1.864 & 0.063 \\
\hline
\end{tabular}


Table A13. Lithuania 2015.

\begin{tabular}{ccccc}
\hline & Estimate & SE & T Statistic & $p$-Value \\
\hline (Intercept $)$ & 10.850 & 1.496 & 7.254 & 0.000 \\
capital & -0.189 & 0.151 & -1.254 & 0.210 \\
labour & 2.309 & 0.534 & 4.323 & 0.000 \\
land & 0.355 & 0.293 & 1.211 & 0.226 \\
ic & -0.876 & 0.340 & -2.576 & 0.010 \\
$\mathrm{I}\left(0.5^{*}\right.$ capital`2) & 0.016 & 0.006 & 2.624 & 0.009 \\
$\mathrm{I}\left(0.5^{*}\right.$ labour^2) & 0.116 & 0.108 & 1.074 & 0.283 \\
$\mathrm{I}\left(0.5^{*}\right.$ land`2) & 0.143 & 0.025 & 5.738 & 0.000 \\
$\mathrm{I}\left(0.5^{*}\right.$ ic^2) & 0.140 & 0.046 & 3.055 & 0.002 \\
capital:labour & 0.090 & 0.036 & 2.496 & 0.013 \\
capital:land & 0.006 & 0.019 & 0.321 & 0.748 \\
capital:ic & 0.009 & 0.020 & 0.434 & 0.664 \\
labour:land & -0.132 & 0.060 & -2.212 & 0.027 \\
labour:ic & -0.218 & 0.066 & -3.333 & 0.001 \\
land:ic & -0.047 & 0.031 & -1.527 & 0.127 \\
\hline
\end{tabular}

Table A14. Poland 2007.

\begin{tabular}{ccccc}
\hline & Estimate & SE & T Statistic & $p$-Value \\
\hline (Intercept $)$ & 9.756 & 0.448 & 21.797 & 0.000 \\
capital & -0.612 & 0.055 & -11.119 & 0.000 \\
labour & 2.834 & 0.148 & 19.175 & 0.000 \\
land & 0.803 & 0.063 & 12.797 & 0.000 \\
ic & -0.544 & 0.058 & -9.306 & 0.000 \\
$\mathrm{I}\left(0.5^{*}\right.$ capital`2) & 0.096 & 0.005 & 19.116 & 0.000 \\
$\mathrm{I}\left(0.5^{*}\right.$ labour^2) & 0.260 & 0.030 & 8.723 & 0.000 \\
$\mathrm{I}\left(0.5^{*}\right.$ land²) & 0.155 & 0.005 & 29.094 & 0.000 \\
$\mathrm{I}\left(0.5^{*}\right.$ ic²) & 0.097 & 0.003 & 36.599 & 0.000 \\
capital:labour & -0.094 & 0.015 & -6.421 & 0.000 \\
capital:land & -0.072 & 0.006 & -11.562 & 0.000 \\
capital:ic & 0.019 & 0.006 & 3.450 & 0.001 \\
labour:land & -0.018 & 0.010 & -1.795 & 0.073 \\
labour:ic & -0.158 & 0.012 & -12.674 & 0.000 \\
land:ic & -0.031 & 0.004 & -7.359 & 0.000 \\
\hline
\end{tabular}

Table A15. Poland 2015.

\begin{tabular}{ccccc}
\hline & Estimate & SE & T Statistic & $p$-Value \\
\hline (Intercept $)$ & 9.168 & 0.390 & 23.489 & 0.000 \\
capital & -0.472 & 0.043 & -10.910 & 0.000 \\
labour & 1.890 & 0.159 & 11.853 & 0.000 \\
land & 0.369 & 0.069 & 5.323 & 0.000 \\
ic & -0.339 & 0.052 & -6.481 & 0.000 \\
$\mathrm{I}\left(0.5^{*}\right.$ capital^2) & 0.070 & 0.003 & 20.383 & 0.000 \\
$\mathrm{I}\left(0.5^{*}\right.$ labour2 $)$ & 0.273 & 0.038 & 7.190 & 0.000 \\
$\mathrm{I}\left(0.5^{*}\right.$ land^2) & 0.196 & 0.008 & 23.689 & 0.000 \\
$\mathrm{I}\left(0.5^{*}\right.$ ic`2 $^{\wedge}$ & 0.086 & 0.002 & 36.457 & 0.000 \\
capital:labour & -0.028 & 0.016 & -1.791 & 0.073 \\
capital:land & -0.019 & 0.007 & -2.714 & 0.007 \\
capital:ic & 0.009 & 0.005 & 1.645 & 0.100 \\
labour:land & -0.131 & 0.015 & -8.880 & 0.000 \\
labour:ic & -0.095 & 0.012 & -7.902 & 0.000 \\
land:ic & -0.048 & 0.005 & -9.917 & 0.000 \\
\hline
\end{tabular}


Table A16. Romania 2007.

\begin{tabular}{ccccc}
\hline & Estimate & SE & T Statistic & $p$-Value \\
\hline (Intercept $)$ & 7.774 & 0.504 & 15.428 & 0.000 \\
capital & -0.357 & 0.095 & -3.770 & 0.000 \\
labour & 0.524 & 0.279 & 1.876 & 0.061 \\
land & 0.774 & 0.128 & 6.057 & 0.000 \\
ic & 0.019 & 0.106 & 0.179 & 0.858 \\
$\mathrm{I}\left(0.5^{*}\right.$ capital`2) & 0.065 & 0.011 & 6.015 & 0.000 \\
$\mathrm{I}\left(0.5^{*}\right.$ labour^2) & 0.264 & 0.118 & 2.241 & 0.025 \\
$\mathrm{I}\left(0.5^{*}\right.$ land`2) & 0.155 & 0.023 & 6.873 & 0.000 \\
$\mathrm{I}\left(0.5^{*}\right.$ ic^2) & 0.061 & 0.020 & 3.021 & 0.003 \\
capital:labour & 0.113 & 0.041 & 2.760 & 0.006 \\
capital:land & -0.048 & 0.017 & -2.891 & 0.004 \\
capital:ic & -0.013 & 0.013 & -1.029 & 0.304 \\
labour:land & -0.016 & 0.032 & -0.519 & 0.604 \\
labour:ic & -0.168 & 0.035 & -4.746 & 0.000 \\
land:ic & -0.040 & 0.015 & -2.672 & 0.008 \\
\hline
\end{tabular}

Table A17. Romania 2015.

\begin{tabular}{ccccc}
\hline & Estimate & SE & T Statistic & $p$-Value \\
\hline (Intercept $)$ & 7.360 & 0.295 & 24.989 & 0.000 \\
capital & -0.156 & 0.044 & -3.535 & 0.000 \\
labour & 0.620 & 0.264 & 2.351 & 0.019 \\
land & 0.838 & 0.077 & 10.830 & 0.000 \\
ic & -0.220 & 0.048 & -4.573 & 0.000 \\
$\mathrm{I}\left(0.5^{*}\right.$ capital`2) & 0.033 & 0.006 & 5.411 & 0.000 \\
$\mathrm{I}\left(0.5^{*}\right.$ labour^2) & 0.128 & 0.132 & 0.975 & 0.330 \\
$\mathrm{I}\left(0.5^{*}\right.$ land²) & 0.134 & 0.010 & 12.844 & 0.000 \\
$\mathrm{I}\left(0.5^{*}\right.$ ic²) & 0.041 & 0.004 & 9.782 & 0.000 \\
capital:labour & 0.061 & 0.031 & 1.931 & 0.054 \\
capital:land & -0.039 & 0.007 & -5.445 & 0.000 \\
capital:ic & 0.016 & 0.005 & 3.265 & 0.001 \\
labour:land & -0.187 & 0.028 & -6.568 & 0.000 \\
labour:ic & -0.039 & 0.023 & -1.679 & 0.093 \\
land:ic & -0.032 & 0.005 & -5.849 & 0.000 \\
\hline
\end{tabular}

Table A18. Slovakia 2007.

\begin{tabular}{ccccc}
\hline & Estimate & SE & T Statistic & $p$-Value \\
\hline (Intercept $)$ & 4.237 & 2.577 & 1.644 & 0.102 \\
capital & 0.457 & 0.185 & 2.470 & 0.014 \\
labour & -0.137 & 0.747 & -0.184 & 0.854 \\
land & -0.490 & 0.549 & -0.892 & 0.373 \\
ic & 0.537 & 0.632 & 0.851 & 0.396 \\
$\mathrm{I}\left(0.5^{*}\right.$ capital`2) & 0.032 & 0.010 & 3.123 & 0.002 \\
$\mathrm{I}\left(0.5^{*}\right.$ labour^2) & 0.475 & 0.161 & 2.948 & 0.004 \\
$\mathrm{I}\left(0.5^{*}\right.$ land² $)$ & 0.384 & 0.120 & 3.211 & 0.002 \\
$\mathrm{I}\left(0.5^{*}\right.$ ic^2) & -0.026 & 0.089 & -0.294 & 0.769 \\
capital:labour & -0.015 & 0.033 & -0.462 & 0.645 \\
capital:land & -0.092 & 0.041 & -2.237 & 0.026 \\
capital:ic & -0.023 & 0.026 & -0.887 & 0.376 \\
labour:land & -0.301 & 0.093 & -3.258 & 0.001 \\
labour:ic & 0.121 & 0.091 & 1.321 & 0.188 \\
land:ic & 0.029 & 0.078 & 0.367 & 0.714 \\
\hline
\end{tabular}


Table A19. Slovakia 2015.

\begin{tabular}{ccccc}
\hline & Estimate & SE & T Statistic & $p$-Value \\
\hline (Intercept $)$ & 9.736 & 3.581 & 2.719 & 0.007 \\
capital & -0.003 & 0.189 & -0.017 & 0.986 \\
labour & 1.446 & 0.893 & 1.619 & 0.107 \\
land & -0.473 & 0.795 & -0.595 & 0.552 \\
ic & -0.109 & 0.709 & -0.153 & 0.879 \\
$\mathrm{I}\left(0.5^{*}\right.$ capital`2) & 0.007 & 0.010 & 0.685 & 0.494 \\
$\mathrm{I}\left(0.5^{*}\right.$ labour^2) & 0.464 & 0.162 & 2.873 & 0.005 \\
$\mathrm{I}\left(0.5^{*}\right.$ land² $)$ & 0.135 & 0.065 & 2.074 & 0.039 \\
$\mathrm{I}\left(0.5^{*}\right.$ ic^2) & 0.024 & 0.092 & 0.261 & 0.794 \\
capital:labour & 0.017 & 0.037 & 0.449 & 0.654 \\
capital:land & 0.039 & 0.041 & 0.958 & 0.339 \\
capital:ic & -0.021 & 0.023 & -0.896 & 0.371 \\
labour:land & -0.425 & 0.102 & -4.156 & 0.000 \\
labour:ic & 0.018 & 0.092 & 0.193 & 0.848 \\
land:ic & 0.041 & 0.083 & 0.494 & 0.622 \\
\hline
\end{tabular}

Table A20. Slovenia 2007.

\begin{tabular}{ccccc}
\hline & Estimate & SE & T Statistic & $p$-Value \\
\hline (Intercept $)$ & 12.939 & 1.697 & 7.624 & 0.000 \\
capital & -0.719 & 0.293 & -2.456 & 0.014 \\
labour & 1.341 & 0.643 & 2.087 & 0.037 \\
land & 0.967 & 0.519 & 1.863 & 0.063 \\
ic & -0.890 & 0.222 & -4.016 & 0.000 \\
$\mathrm{I}\left(0.5^{*}\right.$ capital`2) & 0.070 & 0.035 & 1.990 & 0.047 \\
$\mathrm{I}\left(0.5^{*}\right.$ labour^2) & 0.069 & 0.194 & 0.353 & 0.724 \\
$\mathrm{I}\left(0.5^{*}\right.$ land² $)$ & -0.188 & 0.096 & -1.966 & 0.050 \\
$\mathrm{I}\left(0.5^{*}\right.$ ic^2) & 0.120 & 0.012 & 9.734 & 0.000 \\
capital:labour & -0.174 & 0.071 & -2.461 & 0.014 \\
capital:land & 0.036 & 0.057 & 0.635 & 0.526 \\
capital:ic & 0.021 & 0.024 & 0.855 & 0.393 \\
labour:land & 0.104 & 0.096 & 1.077 & 0.282 \\
labour:ic & 0.076 & 0.034 & 2.192 & 0.029 \\
land:ic & -0.060 & 0.033 & -1.834 & 0.067 \\
\hline
\end{tabular}

Table A21. Slovenia 2015.

\begin{tabular}{ccccc}
\hline & Estimate & SE & T Statistic & $p$-Value \\
\hline (Intercept $)$ & 14.087 & 2.347 & 6.003 & 0.000 \\
capital & -0.711 & 0.349 & -2.038 & 0.042 \\
labour & 3.297 & 0.897 & 3.676 & 0.000 \\
land & 0.961 & 0.575 & 1.672 & 0.095 \\
ic & -1.211 & 0.343 & -3.527 & 0.000 \\
$\mathrm{I}\left(0.5^{*}\right.$ capital^2) & -0.003 & 0.038 & -0.068 & 0.946 \\
$\mathrm{I}\left(0.5^{*}\right.$ labour2 $)$ & 0.180 & 0.156 & 1.154 & 0.249 \\
$\mathrm{I}\left(0.5^{*}\right.$ land^2 $)$ & 0.058 & 0.083 & 0.694 & 0.488 \\
$\mathrm{I}\left(0.5^{*}\right.$ ic^2) & 0.150 & 0.043 & 3.512 & 0.000 \\
capital:labour & -0.071 & 0.079 & -0.900 & 0.368 \\
capital:land & 0.101 & 0.054 & 1.863 & 0.063 \\
capital:ic & 0.076 & 0.035 & 2.154 & 0.032 \\
labour:land & 0.128 & 0.104 & 1.239 & 0.216 \\
labour:ic & -0.237 & 0.077 & -3.066 & 0.002 \\
land:ic & -0.213 & 0.057 & -3.714 & 0.000 \\
\hline
\end{tabular}




\section{References}

1. Lobley, M.; Errington, A.; McGeorge, A. Implications of Changes in the Structure of Agricultural Businesses; Defra: London, UK, 2002.

2. Goddard, E.; Weersink, A.; Chen, K.; Turvey, C.G. Economics of Structural Change. Can. J. Agric. Econ. 1993, 41, 475-489. [CrossRef]

3. Davidova, S.; Thomson, K. Family Farming in Europe: Challenges and Prospects. In-Depth Analysis for the AGRI Committee, European Parliament, Agriculture and Rural Development. 2014. Available online: https:/ /www.Europarl.Europa.eu/RegData/ etudes/note/join/2014/529047/IPOL-AGRI_NT(2014)529047_EN.pdf (accessed on 5 June 2021).

4. Matthews, A. Family Farming and the Role of Policy in the EU. 2013. Available online: http://capreform.eu/family-farmingand-the-role-of-policy-in-the-eu (accessed on 27 May 2021).

5. Agriculture and Rural Development, FADN: Field of Survey. Available online: https://ec.Europa.eu/agriculture/rica/ methodology1_en.cfm\#tfoococf (accessed on 8 June 2021).

6. Oaxaca, R. Male-Female Wage Differentials in Urban Labor Markets. Int. Econ. Rev. 1973, 14, 693-709. [CrossRef]

7. Blinder, A.S. Wage Discrimination: Reduced Form and Structural Estimates. J. Hum. Resour. 1973, 8, 436-455. [CrossRef]

8. Mancours, K.; Swinnen, J. Causes of Output Decline in Economic Transition: The Case of Central and Eastern European Agriculture; Policy Research Group Working Paper No. 11; Department of Agricultural Economics, Katholieke Universiteit Leuven: Leuven, Belgium, 1997.

9. Zecchini, S. (Ed.) Lessons from the Economic Transition. Central and Eastern Europe in the 1990s; Kluwer Academic Publishers: Dordrecht, The Netherlands, 1997; p. 594.

10. Åslund, A.; Boone, P.; Johnson, S.; Fischer, S.; Ickes, B.W. How to Stabilize: Lessons from Post-Communist Countries; Brookings Papers on Economic Activity; Brookings Institution Press: Washington, DC, USA, 1996; Volume 1996, pp. 217-313.

11. Swinnen, J. Ten Years of Transition in Central and Eastern European Agriculture. In Proceedings of the KATO Symposium, Berlin, Germany, 2-4 November 2000; Available online: https:/ /www.researchgate.net/publication/228377542_Ten_years_of_ transition_in_Central_and_Eastern_European_agriculture (accessed on 31 May 2021).

12. Hartvigsen, M. Land Reform in Central and Eastern Europe after 1989 and Its Outcome in the Form of Farm Structures and Land Fragmentation; Land Tenure Working Paper 24; FAO: Rome, Italy, 2013.

13. Balmann, A.; Valentinov, V. Towards a Theory of Structural Change in Agriculture: Just Economics? In Proceedings of the 149th EAAE Seminar 'Structural Change in Agri-Food Chains: New Relations between Farm Sector, Food Industry and Retail Sector', Rennes, France, 27-28 October 2016.

14. Jann, B. The Blinder-Oaxaca Decomposition for Linear Regression Models. Stata J. 2008, 8, 453-479. [CrossRef] 